\title{
ŽIVOT KNJIGE - ZAŠTITA PISANE BAŠTINE U KNJIŽNICI ZAGREBAČKOG PRAVNOG FAKULTETA
}

\author{
LIFE OF BOOK - THE PRESERVATION OF WRITTEN \\ HERITAGE IN THE LAW LIBRARY, FACULTY OF LAW, \\ UNIVERSITY OF ZAGREB
}

\author{
Andrea Horić \\ Pravni fakultet \\ Sveučilište u Zagrebu \\ ahoric@pravo.hr \\ Goran Vržina \\ Acos, Zagreb \\ acosgv@gmail.com
}

\author{
UDK / UDC [025.7/.9:09]:[37:027.7](497.5 Zagreb) \\ Stručni rad / Professional paper \\ Primljeno / Received: 11. 5. 2018. \\ Prihvaćeno / Accepted: 3. 12. 2018.
}

\section{Sažetak}

Cilj. Cilj je ovog rada upoznati širu stručnu zajednicu s iskustvom i praksom na području zaštite i trajnog očuvanja rijetkih i vrijednih knjiga pravne tematike koje imaju status kulturnog dobra u Knjižnici Pravnog fakulteta Sveučilišta u Zagrebu te pritom naglasiti važnost i ulogu knjižnica u tom području.

Pristup. Nakon sažetog pregleda karaktera i svojstava zbirke rijetkosti koja je upisana u Registar kulturnih dobara Republike Hrvatske, rad je predstavio način njezine zaštite i očuvanja provedbom konzervatorsko-restauratorskih tehnika i postupaka te digitalizacije putem sustava za neinvazivnu low light digitalizaciju na primjeru izvornika iz 16. stoljeća.

Rezultati. Prati se put identificiranja, odabira, zaštite, očuvanja te prezentacije mogućnosti očuvanja pisane baštine.

Vjesnik bibliotekara Hrvatske 62, 1(2019), 383-404

ISSN 0507-1925

(C) VBH 2018. 
Praktična primjena. Kroz prikaz primjera zaštite i očuvanja konkretnog primjerka iz 16. st. skreće se pozornost znanstvene i stručne zajednice i srodnih profesija na mogućnosti neinvazivne digitalizacije.

Društveni značaj. Knjižničarskoj i srodnim profesijama, ali i široj javnosti, skreće se pozornost na vrijednu baštinu iz fonda Knjižnice Pravnog fakulteta u Zagrebu, koja kroz primjenu moderne tehnologije postaje dostupna za korištenje.

Originalnost. Ovaj rad opisuje i prati do sada neobjavljene podatke o vrijednoj pisanoj baštini Knjižnice Pravnog fakulteta u Zagrebu, kao i nove metode očuvanja i korištenja te baštine kroz moderne tehnologije.

Ključne riječi: knjižnice, konzervatorsko-restauratorske tehnike i postupci, low light digitalizacija, pisana baština, zaštita

\section{Abstract}

Purpose. The main purpose of this paper is to familiarize the wider professional community with experiences and practices in the field of protection and permanent preservation of rare and valuable law books that have the status of cultural heritage at the Faculty of Law of the University of Zagreb, and to emphasize the importance and the role of libraries in this field.

Approach. After a concise review of character and properties of the rare collection inscribed in The Register of Cultural Goods of the Republic of Croatia, the paper presents the mode of its conservation and preservation by implementing conservation and restoration techniques and procedures along with digitalization by means of the non-invasive low light digitization on the example of an original item from the 16th century.

Findings. The paper follows the path of identifying, selecting, protecting, preserving, and presenting the possibilities of preserving the written heritage.

Practical implications. Through the presentation of an example of the protection and preservation of an original item from the 16th century, the attention of the scientific and professional community and related professions is drawn to the possibilities of non-invasive digitalization.

Social implications. The paper emphasizes the immensely valuable heritage of the Library of the Faculty of Law in Zagreb, to librarians and related professions, as well as the general public, which, through the use of modern technology becomes available for use.

Originality. This paper describes and follows up the unpublished data on the valuable written heritage of the Faculty of Law Library in Zagreb as well as new methods of preserving and using this heritage through modern technology.

Keywords: conservation and restoration techniques, libraries, low light digitization, protection, written heritage 


\section{Uvod}

U Knjižnici Pravnog fakulteta Sveučilišta u Zagrebu oduvijek se posebna pažnja pridavala prikupljanju starih knjiga pravne tematike hrvatskih i inozemnih autora, nastavnih pomagala u autorstvu nastavnika Fakulteta od njegova osnutka do danas te rijetkih tiskanih djela s područja društvenih i humanističkih znanosti (poglavito prava, povijesti, jezikoslovlja, filozofije), uz manji broj teoloških djela. Knjižnični fond obogaćivan je knjigama i odabranim naslovima pravne periodike iz ostavštine Aleksandra Bresztyenszkog, Josipa Pliverića, Aleksandra Egersdorfera, Josipa Šilovića ${ }^{1}$, predmetnih nastavnika Fakulteta te pojedinih uglednika i privatnih osoba iz pravne profesije. Zahvaljujući vrijednim ostavštinama nastavnika Fakulteta, kao i intenzivnoj razmjeni s Harvard Law School, Cambridge, Massaschusets, u razdoblju između 1950. i 1954. godine knjižni je fond obogaćen rijetkim tiskanim izdanjima iz 16. (Cinquecentine) i 17. stoljeća (Seicentine).

U skladu sa svojim poslanjem baštinske ustanove ${ }^{2}$, poštujući međunarodne norme i važeće zakonodavstvo na nacionalnoj razini, poglavito Zakon o knjižnicama $^{3}$, Pravilnik o zaštiti knjižnične građe ${ }^{4}$ te IFLA-ina načela za skrb i rukovanje knjižničnom građom ${ }^{5}$, Knjižnica sustavno skrbi o knjižničnom fondu u cjelini, osobito o rijetkoj i staroj knjižnoj građi baštinske vrijednosti. ${ }^{6}$ Organizacija i način upravljanja zaštitom knjižnične građe polazi od poimanja Michèle Valerie Cloonan koja upozorava na potrebu šireg promišljanja zaštite kulturne baštine u njezinoj široj društvenoj dimenziji te na nužnost razmatranja njezinih kulturoloških aspekata. Prema mišljenju spomenute autorice, zaštita nije samo skup tehničkih problema i rješenja, ona je način gledanja na svijet i skup aktivnosti koji otvara nove načine suradnje među baštinskim institucijama i stručnjacima s različitih područja (umjetnosti, humanističkih znanosti, inženjeringa, arhitekture, računalne znanosti i industrije). ${ }^{7} \mathrm{Na}$ potrebu racionalnog i sustavnog pristupa te važnost dobrog up-

1 Tomečak, B. Biblioteka Pravnog fakulteta u Zagrebu: pregled stvaranja knjižnične zbirke i uređenja knjižnice 1886-1964. // Pravni fakultet u Zagrebu / [urednik Željko Pavić]. Zagreb: Pravni fakultet, 1996. Knj. II, sv.1; str. 631-667.

2 „Očuvati knjižni fond i druge informacijske resurse za sadašnje i buduće generacije“ osobita je misija Knjižnice istaknuta i u internom strateškom dokumentu Strateški plan razvoja Knjižnice Pravnog fakulteta Sveučilišta u Zagrebu 2016-2021. Zagreb: Pravni fakultet, 2016. Str.11.

3 Usp. Zakon o knjižnicama: pročišćeni tekst zakona: NN 105/97, 05/98/ 104/00, 69/09. // Zakon. hr. [citirano: 2018-11-01]. Dostupno na: https://www.zakon.hr/z/745/Zakon-o-knji\%C5\%BEnicama.

4 Pravilnik o zaštiti knjižnične građe. // Narodne novine 52, 1001(2005). [citirano: 2018-11-01]. Dostupno na: https://narodne-novine.nn.hr/clanci/sluzbeni/2005_04_52_1001.html.

5 IFLA-ina načela za skrb i rukovanje knjižničnom građom. Zagreb: Hrvatsko knjižničarsko društvo, 2003.

6 Valja naglasiti da je Hrvatska kao država članica UNESCO-a i Europske unije dužna poštivati načela i uskladiti svoje međunarodne obveze s razvojem i primjenom politika i instrumenata koji potiču i čuvaju kulturnu raznolikost.

7 Cloonan, M. V. W(h)ither preservation? // The Library Quarterly 71, 2(2001), str. 232, 235. [citirano 2018-03-08]. Dostupno: http://www.jstor.org/stable/4309507. 
ravljanja i organizacije zaštite kao integralnog dijela svakodnevnog knjižničnog poslovanja upozoravaju i hrvatski autori i stručnjaci s toga područja. ${ }^{8}$ Valja naglasiti da se u svakodnevnoj knjižničnoj praksi i svijesti pod pojmom „zaštite“ podrazumijeva „odgovorno skrbništvo“ koje uključuje sve politike i mogućnosti djelovanja, uključujući i konzervatorsko-restauratorske postupke. ${ }^{9}$

Imajući u vidu korisničke, materijalne, ali i društvene, aspekte zaštite pisane baštine u knjižnicama, pored primjerenih uvjeta za dugoročno čuvanje i pohra$\mathrm{nu}^{10}$, brižljivog rukovanja i određenih ograničenja i uvjeta dostupnosti, za navedenu se građu osigurava preventivna i kurativna zaštita (primjenom konzervatorsko-restauratorskih postupaka) te zaštita prijenosom u drugi medij (digitalizacija).

S obzirom na to da je zaštita pisane baštine u knjižnicama izuzetno složeno i zahtjevno područje u teorijskom i praktičnom smislu koje je bitno povezano s kulturološkom i društvenom vrijednošću identiteta i povijesti ${ }^{11}$, rad želi na praktičnom primjeru primjene određenih aktivnosti zaštite rijetke knjižne građe ukazati na važnost i ulogu knjižnice kao fizičkog mjesta za promociju kulture, skrb za očuvanje pismene baštine te izgradnju i razmjenu društvenog kapitala ${ }^{12}$.

Uzimajući u obzir činjenicu da je vrijednost stare knjige sadržana u neodvojivosti duhovnog sadržaja i materijalne ovojnice, primijenjena su dva oblika zaštite rijetkog izvornika iz 16. stoljeća: konzervatorsko-restauratorski postupak i prijenos u drugi medij uz pomoć sustava za neinvanzivnu digitalizaciju s niskom razinom svjetla ispod 50 luksa. Digitalna tehnologija u ovom je slučaju primijenjena s ciljem zaštite izvornika, što je u skladu sa shvaćanjem Paula Conwaya o

8 Hasenay, D.; M. Krtalić. Terminološki i metodološki aspekti u proučavanju zaštite stare knjižnične građe. // Libellarium 1, 2(2008), str. 204. [citirano 2018-03-01]. Dostupno: https://hrcak.srce.hr/37156.

9 Usp. The relevance of preservation in a digital world. // NEDCC preservation leaflets. [citirano: 2018-02-05]. Dostupno na: https://www.nedcc.org/free-resources/preservation-leaflets/6.-reformatting/6.4-the-relevance-of-preservation-in-a-digital-world.

10 Jean Ann Croft u svom članku iz 2003. otvara cijeli niz tema vezanih uz problem i pojam zaštite kulturne baštine od odgovornosti za primjerenu skrb o kulturnom predmetu i primjercima arhivske građe, problemima udaljenih spremišta i/ili nedostatnosti prostora za pohranu građe, o potrebi educiranja stručnih osoba kojima je građa povjerena te o upravljanju u kriznim situacijama kao što su ratna razaranja ili terorističke aktivnosti. Vidjeti: Croft, J.A. The preservation evolution: a review of preservation literature, 1999-2001. // Library Resources and Technical Services 47, 2(2003), 59-71. [citirano 2018-03-01]. Dostupno na: https://ia800707.us.archive.org/0/items/ lrtsv47no2/lrtsv47no2.pdf. O nekima od navedenih problemima, poglavito nedostatku financijskih sredstava i primjerenog prostora za smještaj građe, vidjeti i: Krtalić, M.; T. Čop; D. Hasenay. Organizacijske pretpostavke zaštite knjižne baštine u samostanskim knjižnicama. // Libellarium 3, 2(2010), 113-134. [citirano 2018-01-28]. Dostupno na: https://hrcak.srce.hr/file/115519.

11 Krtalić, M.; D. Hasenay; T. Aparac-Jelušić. Upravljanje zaštitom pisane baštine u knjižnicama: teorijske pretpostavke. // Vjesnik bibliotekara Hrvatske 54, 1-2(2011), str. 5, 11-12.

12 Gorman, M. The wrong path and the right path: the role of libraries in access to, and preservation of, cultural heritage. // New Library World 108, 11/12(2007), str. 482. Dostupno na: https:// doi.org/10.1108/03074800710838236. 
tri različite, ali ne i međusobno isključive primjene digitalne tehnologije: zaštita izvornika, reprodukcija izvornika i transcendiranje izvornika. ${ }^{13}$

Valja naglasiti da je prilikom provedbe navedenih oblika zaštite postojala svijest o iznimnoj materijalnoj i duhovnoj vrijednosti, kao i o jedinstvenosti primjerka te potrebi da se istraživačima stare knjige i pravnim znanstvenicima osigura pristup vrijednim podacima poput ekslibrisa, tiskarskih znakova, potpisa, načina uveza i fizionomije knjižnog bloka, gravura na koricama, pravnoj ikonografiji (primjerice simbolički i likovni prikazi pravde i pravosuđa) i cijelom nizu metainformacija vezanih uz primjerak.

Na primjeru jedinice tiskane građe iz 16. stoljeća rad daje uvid u provedbu konzervatorsko-restauratorskih tehnika i postupaka u svrhu očuvanja primjerka u njegovu izvornom obliku i zadržavanju čitljivosti, njegove temeljne funkcije. Rad također opisuje oblik dodatne zaštite prijenosom na drugi medij dajući detaljan uvid u proces i karakteristike neinvanzivne digitalizacije s niskom razinom svjetla ispod 50 luksa.

\section{Zbirka rijetkosti Knjižnice Pravnog fakulteta}

Zbirku rijetkosti Knjižnice Pravnog fakulteta u Zagrebu (Rara) čini četrdeset devet jedinica tiskane knjižne građe iz 16. (Cinquecentine) i 17. stoljeća (Seicentine) s područja društvenih i humanističkih znanosti. ${ }^{14}$ Riječ je o najstarijim i najvrjednijim knjigama iz rimskog, kaznenog, kaznenog postupovnog i kanonskog prava, opće i pravne povijesti te o rijetkim djelima s područja pravne teorije, psihologije i filozofije. ${ }^{15} \mathrm{U}$ zbirci se nalazi dvadeset devet cinquecentina, među kojima je i postinkunabula Decretales, Gregorii IX, tiskana u Lyonu 1528. Među dvadeset knjiga objavljenih u 17. stoljeću treba istaknuti rijetka djela Corpus

13 Conway, P. Rationale for digitization and preservation. // Handbook for digital projects: a management tool for preservation and acess / ed. by Maxine K. Sitts. Andover, Massachusetts: Northeast Document Conservation Center, 2000. Str. 15, 17-18. [citirano 2018-02-15]. Dostupno na: https://www.nedcc.org/assets/media/documents/dman.pdf.

14 Prilikom oblikovanja zbirke rukovodilo se kriterijem vremena (djela tiskana od Guttenbergova izuma tiskarskog stroja (1455.) do, u hrvatskom slučaju, 1835.), predmetnog područja (pravo), vrijednosti i ugroženosti primjerka. O kriterijima koji knjigu označuju rijetkom i starom vidjeti: Jurić, Š. Stara i rijetka građa. // Seminar Standardiziranje kataložne obrade stare i rijetke građe, Zagreb, 10-11. prosinca 1992. / ur. Tinka Katić. Zagreb: Nacionalna i sveučilišna biblioteka, 1993. Str. 3-5; Katić, T. Stara knjiga: bibliografska organizacija informacija. Zagreb: Hrvatsko knjižničarsko društvo, 2007. Str. 39-41.

15 Knjige su signirane dvodijelnom oznakom u kojoj rimski broj označava stručnu skupinu građe, a arapski broj označava pojedinačno izdanje knjige određenog naslova određenog autora. Zbirku čine dvije jedinice pod rimskim brojem III s područja kaznenog materijalnog i kaznenog postupovnog prava, pet jedinica pod rimskim brojem V s područja filozofije prava, pravne teorije i filozofije, dvadeset šest jedinica pod rimskim brojem VII s područja rimskog prava, sedam jedinica pod rimskim brojem IX s područja opće povijesti i pravne povijesti te sedam jedinica pod rimskim brojem X s područja kanonskog prava. 
Iuris Civilis : In quatuor Partes distinctum ; Cui Appendicis Et Auctarii Loco, Aliquot, Quae prioribus huius formae Editionibus defuerunt, adiecta sunt, Inprimis Francisci Modii IC. Brugensis ad omnes L. Pandectarum \& XII. Codicis Libros Notae... iz 1663. te In Quatuor Libros Institutionum Imperialium Commentarius Academicus Et Forensis, Amstelodanni iz 1665. Dionysiusa Gothofredusa (Godefroi, 1549.-1622.) i Arnolda Vinniusa (1588.-1657.). ${ }^{16}$ Valja naglasiti da su djela iz 17. stoljeća čiji je autor Dionysius Gothofredus (značajan jer je objedinio i prvi kao cjelinu objavio Justinijanovu kodifikaciju pod nazivom Corpus iuris civilis) iznimno dobro očuvana te da će im dodatni konzervatorsko-restauratorski postupci trajno očuvati život za buduće generacije pravnika koji će proučavati rimsko pravo. Četvrto izdanje (iz 1614.) spomenutog djela čuva se u zbirci rijetkosti pod signaturom VII - 76. Djelo Fontes quatuor Iuris civilis in unum collection: Puta, Legis XII. Tabvlarvm, objavljeno u Đenovi 1653. brigom Jacobusa Gothofredusa, također se ubraja među rijetka djela iz rimskopravne materije. Zbirka sadrži prvi, drugi i treći dio Justinijanova Digesta iz 16. stoljeća. Riječ je o zbirci pravničkog prava nastaloj 533. godine, a koja se tijekom srednjega vijeka prepisivala te je kasnije i tiskana u tri dijela kao Digestum Vetus, Digestum Novum i Infortiatum. U zbirci se čuvaju i sljedeća djela:

Digestum novum seu pandectarum iuris civilis tomus tertius. Lugduni, 1569. Signatura VII - 179 [Novum, knjige od 39. do 50.]

Digestum vetus seu pandectarum iuris civilis tomus primus. Parisiis, 1576. Signatura VII - 180 [Digestum Vetus, knjige od 1. do 24.]

Infortiatum seu pandectarum iuris civilis torn. 2. Parisiis, 1576. Signatura VII - 181 [Infortiatum, knjige od 24. do 38]

Digestum novum seu pandectarum iuris tomus tertius. Parisiis, 1576. Signatura VII - 182 [Novum, knjige od 39. do 50.]

U zbirci su također zastupljena djela iz kaznenopravne materije, a pritom treba posebno izdvojiti djelo Prosperusa Farinaciusa, vodećeg kaznenopravnog mislioca iz 16. stoljeća, poznatog i pod imenom Prospero Farinacci. Riječ je o prvom svesku drugog dijela izvornog izdanja velikog djela Praxis et theoricae criminelis: Tomus primus, parttis secundae, tiskanog u Veneciji 1607. godine. Navedeno je djelo kompendij jurisprudencije u razdoblju od 1581. do 1614. kao rezultat Farinaciusove velike ambicije da u obliku priručnika za sudove sažme sve ono što je napisano o kaznenom pravu. Djelo je bilo objavljeno u osamnaest kapitula u razdoblju od 1594.

16 Navedeni su autori poznati pravnici iz 17. stoljeća i predstavnici tzv. francuske historičke škole ,elegantne jurisprudencije“, koja je napustila skolastičke metode glosatora i postglosatora te se počela baviti historičko-kritičkim izučavanjem Justinijanova rimskog prava. Usp. Horvat, M. Rimsko pravo. Zagreb: Pravni fakultet Sveučilišta, 2017. Str. 96. 
do 1614. i doživjelo je izvanredan uspjeh jer je više od dva stoljeća korišteno u pravnoj praksi, osobito u Italiji i susjednim zemljama. Ono i danas predstavlja središnji izvor pravne teorije i prakse kaznenog prava u 16. i 17. stoljeću.

Cinquecentina Tractatus de questionibus in quo materie, maleficiorum portraetant : cum tabula $p$ modu numeri et alfabeti nouissime recognit, tiskana u Lyonu 1524., izvorno je izdanje jednog od triju najznačajnijih djela bolonjskog doktora prava Hippolytusa de Marsiliisa (Bolonja, 1451.), poznatog i pod imenom Ippolito Marsigli. Djelo predstavlja traktat s područja kaznenog prava, a bavi se pitanjima vezanim uz pravne stvari koji se odnose na vještice.

Među djelima s područja humanističkih znanosti svakako valja istaknuti rijetko izdanje Opera philosophica Renéa Descartesa (lat. Renatus Cartesius, 1596.1650.) iz 1677., francuskog filozofa i začetnika moderne filozofije, matematike i analitičke geometrije, kao i čuvenu knjigu njemačkih srednjovjekovnih običaja iz 13. stoljeća u redakciji Christopha Zobela, tiskanu u Leipzigu 1569. godine.

Zbog svoje rijetkosti, jedinstvenosti, intelektualne i povijesne vrijednosti, zbirka je izdvojena iz knjižnoga fonda i zaštićena kao pokretno kulturno dobro. Za svaku jedinicu izrađena je kutija po mjeri od beskiselinskog kartona kako bi se zbirka u cjelini zaštitila od unutarnjih i vanjskih uzroka oštećenja te usporio proces starenja i daljnjeg propadanja. ${ }^{17}$ Godine 2012. prijavljena je Gradskom zavodu za zaštitu spomenika kulture i prirode grada Zagreba u trogodišnji program privremene zaštite, dok se od studenog 2015. nalazi na popisu zaštićenih kulturnih dobara u sklopu Registra kulturnih dobara Republike Hrvatske pod brojem Z-6645.

Zbirka je smještena u glavnoj zgradi Fakulteta. Prostor površine $35 \mathrm{~m}^{2}$ čist je, suh, svijetao i prozračan ${ }^{18}$, opremljen klimatizacijskim uređajem podešenim prema optimalnim vrijednostima ${ }^{19}$, uređajem za mjerenje vlage i temperature $\mathrm{s}$ računalnim praćenjem pomoću kojeg se vrši nadzor mikroklime u prostoriji tipa „Datalogger CENTER 342 humidity recorder; S/N: 31102170“20, protuprovalnim

17 S obzirom na cilj i planirani opseg ovoga rada, nije moguće ulaziti u dublju analizu vrsta i načina oštećenja stare i vrijedne knjižnične građe, ali se želi naglasiti da knjižnični zaposlenici posjeduju odgovarajuću razinu znanja o promjenama koje nastaju prirodnim starenjem, a rezultat su fizikalno-kemijskih reakcija oksidacije i kisele hidrolize. Usp. Mušnjak, T. Zaštita pisane baštine od kemijskih uzročnika oštećenja. // Savjetovanje Konzerviranje i restauriranje papira 4: grafički materijal, Ludbreg. Zagreb: Hrvatski restauratorski zavod, 2004. Str.66.

18 Rezultati mjerenja relativne vlažnosti (RV) $(45,5 \%)$ i temperature $\left(19^{\circ} \mathrm{C}\right)$ provedenog u srpnju 2017.

19 IFLA-ina načela. Nav. dj., str. 27.

20 Uređaj je jednostavan za korištenje i predstavlja suvremeno rješenje za nadziranje mikroklimatskih uvjeta u knjižnici jer bilježi podatke o temperaturi i vlazi koji se putem USB-a prenose na računalo. Važno je naglasiti da uređaj sadrži i instalacijske upute na hrvatskom jeziku. Valja naglasiti da se prije nabave mjernog instrumenta vodilo računa o sljedećem: financijskim mogućnostima Fakulteta, broju prostorija u kojima treba obavljati mjerenja te potrebama za pokretnim instrumentom, računalom i znanjem da bi se djelatnici koristili loggerom. Više o instrumentima i 
vratima te zaštitom od sunca na prozorima. ${ }^{21} \mathrm{U}$ sobi se nalazi stručno osposobljena osoba, zaposlenik Knjižnice. Sve su knjige dokumentirane u inventarnim knjigama, bibliografski obrađene i dostupne u računalnom katalogu online. Valja naglasiti da je u ljeto 2015. izrađen i Operativni plan mjera zaštite knjižnične građe u slučaju opasnosti ${ }^{22}$ sa svrhom povećavanja učinkovitosti djelovanja u kriznim situacijama i umanjivanja rizika od nastanka kriznih situacija na temelju procjene, identifikacije i analize rizika; uspostave odgovarajućeg sustava osiguranja; preciznog definiranja mjera postupanja u kriznim situacijama te mjera obnove nakon štete nastale na knjižničnom fondu, prostoru i opremi. ${ }^{23}$ Plan je sastavljen u skladu s naputcima u novijoj stručnoj literaturi o zaštiti knjižnične građe, nacionalnim i međunarodnim propisima te strukovnim preporukama. ${ }^{24}$

Tijekom trogodišnjeg programa privremene zaštite do upisa na listu zaštićenih kulturnih dobara u Registar (2015. godine), uz financijsku potporu Ministarstva

njihovoj primjeni vidjeti: Laszlo, Ž.; A. Dragojević. Priručnik preventivne zaštite umjetnina na papiru. Zagreb: Crescat, 2010. Str. 33-36.

${ }^{21}$ Ultraljubičasto (UV) zračenje najštetnije je za papir, ono uzrokuje fotokemijsku razgradnju papira jer sadrži energiju dovoljnu za dostizanje energije aktivacije potrebne za početak kemijske reakcije. Usp. Piasevoli, J. Zaštita od štetnog djelovanja svjetla. // Savjetovanje Konzerviranje i restauriranje papira 4: grafickki materijal, Ludbreg. Zagreb: Hrvatski restauratorski zavod, 2004. Str.70-73.

22 Riječ je o internom dokumentu koji se ažurira prema potrebi i u skladu s promjenama.

23 Valja naglasiti specifičnost Knjižnice po dislociranom smještaju osoblja, knjižnične građe i spremišta: na ukupnoj površini od 1.487,50 m2 Knjižnica radi na tri lokacije u gradu. Mjere predviđene Planom donesene su sukladno navedenoj situaciji.

24 Pravilnik o određivanju kulturnih predmeta koji se smatraju nacionalnim blagom država članica Europske unije. // Narodne novine 38, 947(2004). [citirano:2018-11-01]. Dostupno na: https:// narodne-novine.nn.hr/clanci/sluzbeni/2004_03_38_947.html.; Pravilnik o zaštiti od požara. Zagreb: Pravni fakultet Sveučilišta, 2001.; Procjena rizika od katastrofa za Republiku Hrvatsku / Državna uprava za zaštitu i spašavanje. Zagreb, $<2015>$. [citirano 2018-11-02]. Dostupno: https:// www.google.hr/url? sa $=t \& r c t=j \& q=\&$ esrc $=$ s\&source $=$ web\& $c d=1 \&$ cad $=$ rja\&uact $=8 \& v e d=2 a h U-$ KEwi86_PBtLXeAhWrC8AKHYZOAWIQFjAAegQICBAC\&url=http\%3A\%2F\%2Fstari.duzs. hr\%2Fdownload.aspx\%3Ff\%3Ddokumenti\%2FClanci\%2FProcjenarizikaodkatastrofauRH.. pdf\&usg=AOvVaw2JtuhkrfKUTVIx12sAfVmV.

; Upute za pristupanje izradi plana mjera za slučaj opasnosti. [citirano:2018-11-01]. Dostupno na: http://www.nsk.hr/wp-content/uploads/2012/01/Upute-PlanMjera-za-slucaj-opasnosti.pdf; Đardulo, A. Zaštita i konzervacija knjiga: materijali, tehnike i infrastruktura. Beograd: Clio, 2005.; IFLA-in kratki priručnik za pripravnost i planiranje mjera zaštite u slučaju katastrofa. Zagreb: Hrvatsko knjižničarsko društvo, 2012.; Halsted, D. D.; R. P. Jasper; F. M. Little. Disaster planning: a how -to - do -it manual for librarians with planning templates on CD-ROM. New York, London: Neal-Schuman, 2005.; Laszlo, Ž.; B. Perčinić Kavur; H. Stublić, Što činiti u slučaju nesreće, velike nesreće ili katastrofe? // Informatica Museologica 40, (3-4)2009., 134-139. [citirano 2015-05-20]. Dostupno na: http://hrcak.srce.hr/index.php?show=clanak\&id_clanak jezik $=198480$; Kratke smjernice za izradu plana mjera za slučaj opasnosti za narodne knjižnice. Zagreb: Nacionalna i sveučilišna knjižnica: Matična služba za narodne knjižnice. [citirano 201505-20]. Dostupno na: http://www.nsk.hr/wp-content/uploads/2012/10/Kratke-smjernice-za-izradu-plana-mjera-za-slu\%C4\%8Daj-opasnosti-za-narodne-knji\%C5\%BEnice.pdf; Plathe, A. Uneskov program hitnih mjera za zaštitu vitalnog gradiva u slučaju oružanih sukoba. // Arhivski vjesnik 43(2000), 77-90. 
kulture Republike Hrvatske provedeni su restauratorski i konzervatorski radovi na sedam cinquecentina i dvije jedinice iz 17. stoljeća:

Hyppoliti de Marsilijs, Bononiensis. A. interpretis Traetatus de questionibus in quo materie, maleficiorum portraetant : cum tabula p modu numeri et alfabeti nouissime recognit. Laugduni, 1524. Signatura III - 2.228

Sansovino, F. Del governo de regni et delle republiche antiche et moderne. Venetia, 1567. Signatura V -287

Gribaldi, Matthaei. lurisconsulti cheriani. Venetiis, 1552.; Petri Cordati adolescentis bellunensis praeludia. Florentiae, 1553. Signatura V-717 add.1

Gribaldi, Matthaei. Petri Cordati adolescentis bellunensis praeludia. Florentiae, 1553. Signatura V -717 add.2

Farinacius, Prosperi. Praxis et theoricae criminelis : Tomus primus, parttis secundae. Venetiis, 1607. Signatura III - 1.421

Descartes, Renatus. Opera philosophica. Amsterdami : Apud Danielem Elsevirium [Sv.1] ; [Sv.2]; [Sv.3], 1677. Signatura V-1.303 ; [Sv.1] ; Principia philosophiae; [Sv.2] ; Specimina philosophiae: seu dissertatio de methodo - dioptrice et meteora; [Sv.3]; Passiones animae Signatura V - 1.303 ; [Sv.1 -3]

Bartolus a Saxo Ferrato. Digesta nuova Parto 1., Venetiis, 1575.Signatura VII - 191 P.1

Bartolus a Saxo Ferrato. Digesta nuova Parto 2., Venetiis, 1575.Signatura VII - 191 P.2

Cuiacii, Jacobi. Observationum et emendationum : libri 24. Coloniae Agrippinae, 1591. Signatura VII - 466

Stanje građe u trenutku uključivanja u trogodišnji program preventivne i kurativne zaštite 2012. godine bilo je u najvećoj mjeri posljedica niza nepovoljnih mikroklimatskih utjecaja, koji su dugotrajnim djelovanjem uzrokovali teže degradacijske procese na prirodnim makromolekulama celuloznih vlakana od kojih je izrađen papir, kao i degradacije kolagenskih vlakana u koži i pergameni od kojih je izrađena većina knjižnih uveza. Najnepovoljniji mikroklimatski utjecaj na građu imali su neodgovarajuće vrijednosti temperature i relativne vlage zraka, kao i njihove nagle i česte oscilacije u prostorima Knjižnice. Na primjercima građe također je zapažena krtost kožnih i pergamenskih korica, brojna napuknuća na rubovima korica, razdvojenost korica od hrpta knjige te veća deformiranost korica, što je bila izravna posljedica nedostatka vlage, odnosno dehidriranosti kolagenskih vlakana. 
Također valja naglasiti da je na oko 30 \% knjiga došlo do težih oštećenja papira, kože i pergamene razvojem mikroorganizama (različitih vrsta plijesni), što je bilo posebno izraženo na knjigama većeg formata uvezanim u pergamenu. Na manjem broju svezaka bilo je vidljivo djelovanje kukaca koje je rezultiralo pojavom sitnih smeđih kiselih mrlja na površini papira, čime su prouzročena dodatna, ali ne znatnija, oštećenja knjižnih blokova, posebice u sadržajnom smislu.

$\mathrm{Na}$ očuvanost knjižnog fonda u stanovitoj je mjeri utjecao i način smještaja građe na police, kao i vrsta, kvaliteta i veličina polica, o čemu se u prošlosti nije vodilo dovoljno računa. Višekratne selidbe fonda dodatno su pogoršale opće stanje knjižne građe, poglavito voluminoznijih svezaka iz 16. i 17. stoljeća.

Program zaštite obuhvatio je standardne postupke konzervacije oštećenih knjižnih blokova, što se prvotno odnosilo na primjenu postupaka dezinfekcije i neutralizacije kojima su prethodili postupci čišćenja knjižnih blokova metodom list po list, tehnika četkanja, brisanja i ispuhivanja stlačenim zrakom. Nakon navedenih postupaka knjige su restaurirane metodom klasične ručne restauracije i metodom parcijalne laminacije uz upotrebu visokovrijednih restauratorskih materijala i kemikalija.

Restauratorsko-konzervatorske radove na jedinicama u zbirci rijetkosti otpočetka izvode licencirani konzervatori i restauratori. Mjere zaštite i metode pohranjivanja i rukovanja knjižnom građom i periodikom primjenjuju se u skladu s IFLA-inim načelima te važećim strukovnim propisima i preporukama.

\section{Zaštita izvornika iz 16. stoljeća Decretales, Gregorii IX.}

Zbog mnoštva dekretala i zbirki koje su nastale nakon Gracijanova Dekreta papa Grgur IX. (Ugolini di Segni, 1143.-1241.) bulom Rex Pacificus 1234. proglasio je Decretales Gregorii IX. autentičnom, jedinom i ekskluzivnom zbirkom. Time je dokinuta snaga svim ranijim izvorima općega prava, osim onim zakonima koji su sadržani u toj zbirci i u Gracijanovu Dekretu. ${ }^{25}$

Decretales, Gregorii IX. jedna je od zbirki Corpus iuris canonici i jedno od najvažnijih djela iz područja klasičnog kanonskog prava iz srednjega vijeka. Zbirka je kapitalan izvor klasičnog rimskog prava i temelj podučavanja na sveučilištima. Dekretali Grgura IX., neformalno poznati i kao Liber extra, opsežna su zbirka od preko 2000 dekretala ${ }^{26}$ koji su sistematizirani i službeno objavljeni po papi Grguru

25 Usp. Škalabrin, N. Uvod u kanonsko pravo. Zagreb: Katolički bogoslovni fakultet Sveučilišta; Đakovo: Teologija u Đakovu; Osijek: Pravni fakultet Sveučilišta, 1994. Str. 93.

26 Dekretali (lat. epistolae decretales) su u srednjem vijeku bili naredbe i konstitucije papa koje imaju opću važnost, bilo za čitavu Crkvu ili barem za njezin znatni dio. Papinske odredbe imale su snagu zakona, stvarale su crkveno pravo, nazvano dekretalno pravo. Usp. Šalković, J. Kanonsko pravno uređenje u vrijeme Ivana Pavla II. // Ivan Pavao II: poslanje i djelovanje: zbornik radova sa simpozija održanog u Zagrebu 24. lipnja 2005. Zagreb: Glas Koncila, 2005. Str. 288. 
IX. u rujnu 1234. Dekretali su usustavljeni prema shemi koju je ranije u svojemu djelu Breviarium extravagantium postavio Bernard od Pavije u 13. stoljeću. ${ }^{27}$

U zbirci rijetkosti Knjižnice Pravnog fakulteta u Zagrebu pohranjeno je jedno od najranijih izdanja u prvoj polovici 16. stoljeća (slika 1).

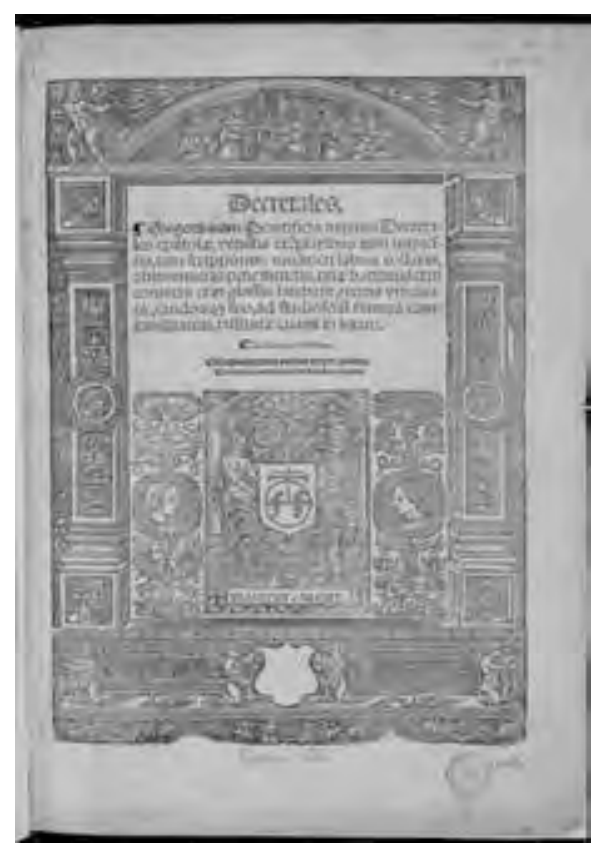

Slikal. Izvornik iz 16. stoljeća

Decretales. Gregorii Noni Pontificis maximi Decretales epistolae, vetuitis exemplaribus turn umpressis, turn scriptis non mediceri labore collatis.ab innumeris penemendis, quae hactenus et in contextu et in glossis latebant, recens vibdictae, ... Lugduni, 1528. Signatura X - 1

Promatrano s gledišta pravne važnosti, važnosti za Fakultet i sveučilište u cjelini, riječ je o iznimno vrijednom i rijetkom djelu. Stoga je upravo taj izvornik, u odnosu na ostala vrijedna i rijetka djela u Zbirci, izdvojen i predložen za program zaštite kulturne baštine Ministarstva kulture Republike Hrvatske.

U daljnjem će tekstu biti opisane mjere zaštite i očuvanja provedbom konzervatorskih i restauratorskih postupaka, kao i digitalizacije pomoću sustava za neinvazivnu low light digitalizaciju.

27 Usp. Brundage, J. Medieval canon law. London, New York: Longman, 1995. Str. 55; Detaljnije informacije o shemi koju je postavio Bernard iz Pavije dostupne su na elektroničkoj lokaciji pod enciklopedijskom natuknicom „Breviarium extravagantum“: https://www.britannica.com/ topic/Breviarium-extravagantium. 


\subsection{Konzervatorsko-restauratorski postupci na knjizi}

U okviru odobrenog programa zaštite i očuvanja pokretnih kulturnih dobara za 2015. godinu Ministarstva kulture Republike Hrvatske, na navedenom su izvorniku iz 16. stoljeća provedeni složeni konzervatorsko-restauratorski postupci. Isti su planirani na temelju detaljnog i stručnog pregleda knjižne građe od strane licenciranih konzervatora i restauratora: višeg konzervatora i restauratora Jelene Piasevoli-Mikac i konzervatora restauratora Velimira Mikca iz Zagreba.

Pregledom su na jedinici rijetke tiskane knjižne građe utvrđena oštećenja mehaničkog, fizikalnog i biološkog karaktera. Oštećenja fizičke ovojnice, „tijela knjige“, utvrđena su na brojnim mjestima - koricama, hrptu, knjižnom bloku i listovima - te su uključena u projektni plan i predviđena njime. Dio poslova koje su konzervatori i restauratori izveli na jedinici građe nisu se međutim mogli predvidjeti početnim projektnim planom, kao primjerice nalaz mnoštva tiskanih materijala i ponešto rukopisa koji su zajedno slijepljeni tvorili „koricu“ i čije je razdvajanje iznimno produljilo sam proces restauracije jer je potrebno puno vremena i znanja da se slijepljeni listovi rasloje, očiste, konzerviraju i restauriraju.

Radovi na restauraciji i konzervaciji izvornika iz 16. stoljeća odvijali su se u fazama, a obuhvatili su

- mehaničko čišćenje listova papira i korica

- konzervaciju i neutralizaciju

- restauriranje listova knjige te listova koji su bili slijepljeni i imali formu korice

- sušenje i ravnanje

- restauraciju izvornih korica ${ }^{28}$

- fotografiranje procesa restauracije prije, za vrijeme i nakon završetka radova

- izradu opsežne fotodokumentacije.

Svi postupci i procesi koji su bili uključeni u provedbu konzervatorsko-restauratorskih zahvata na izvorniku iz zbirke knjižnične zbirke rijetkosti strogo su se rukovodili načelima struke ${ }^{29}$, važećim propisima i pripadajućim standardi-

28 Valja upozoriti da se u koricama starih i rijetkih knjiga često nalaze fragmenti različitih rukopisa, na papiru ili pergameni, koji su poslužili kao knjigoveški materijal za uvez. Takvi su fragmenti u pravilu stariji od same knjige, često i vredniji od nje te mogu biti izvor velikoga broja informacija, od samoga zapisa na njima do utvrđivanja razdoblja uveza ili čak radionice u kojoj je knjiga uvezana. Na to je upozorila Jelena Piasevoli Mikac u svom izlaganju pod naslovom „Rukopisni i tiskani fragmenti iz korica starih knjiga“ $u$ okviru nedavno održanog stručnog skupa u Hrvatskom državnom arhivu „Susret konzervatora i restauratora arhivskog i knjižnog gradiva i umjetnina na papiru“. Hrvatski državni arhiv, Zagreb, 25. i 26. rujna 2018. Više o temi uvezivanja starih i rijetkih knjiga vidi $\mathrm{i}$ u: Medieval manuscripts: bookbinding terms, materials, methods, and models. [citirano 2018-0913]. Dostupno: https://travelingscriptorium.files.wordpress.com/2013/07/bookbinding-booklet.pdf.

29 Riječ je o načelima: 1) maksimalnog očuvanja izvornih dijelova; 2) korištenja materijala konzervatorske kvalitete koji su kompatibilni s izvornikom te 3) reverzibilnosti, tj. načelu prema kojem se predmet uvijek može vratiti u stanje prije konzervatorsko-restauratorskih postupaka, a da 
ma. ${ }^{30}$ Navedeno se odnosi i na korištene materijale ${ }^{31}$ koji su svojom kvalitetom u potpunosti udovoljili pravilima struke. S ciljem očuvanja uveza ovog rijetkog primjerka tiskane knjižne građe od utjecaja vlage, bioloških oštećenja i ostalih nepoželjnih utjecaja, izrađena je i posebna zaštitna kutija po mjeri. Zaštitna je kutija izrađena od neutralne muzejske ljepenke presvučene smeđim platnom s naslovom knjige na prednjoj korici (slika 2).

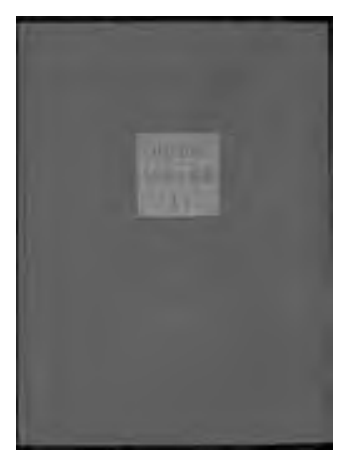

Slika 2 Zaštitna kutija za izvornik iz 16. stoljeća32

Navedenim je postupcima, izvedenima na „tijelu knjige“, osnažen život jedinice iz 16. stoljeća u njezinoj fizičkoj, materijalnoj i duhovnoj dimenziji. Pohranjena u zbirku rijetkosti, knjiga je očuvana za buduće generacije znanstvenika i istraživača. Daljnji život knjige, zaštićen od propadanja i štetne uporabe, potvrđuje da struktura i oblik nastavljaju život u prostoru, trajnost materijala svjedoči o vremenu, dok njezino značenje ima specifičnu ulogu ne samo u matičnoj akademskoj i široj znanstvenoj zajednici već i u društvu u cjelini. ${ }^{33}$

se dodatno ne uništava. Osobito je važno sve procese detaljno dokumentirati i izraditi kvalitetnu fotodokumentaciju. Više o toj problematici i načelima: Smjernice konzervatorsko-restauratorskog rada / priredio Denis Vokić. Dubrovnik; Zagreb: K-R Centar, 2007.

30 Zakon o knjižnicama. Nav. dj.; Pravilnik o zaštiti knjižnične. Nav. dj.; IFLA-ina načela. Nav. dj. ; Laszlo, Ž.; A. Dragojević. Nav. dj. ; Medieval manuscripts: Nav. dj.

31 Japanski papir za popunjavanje i djelomično prekrivanje površine listova (nekoliko vrsta i gramatura japanskog papira), metil-celuloza (Tylose), klucel G ljepilo, škrobno ljepilo, kanadsko brašno nabavljeno iz Engleske koje je termički dugotrajno obrađeno ljepilo, konac od kudelje i lana, neutralni papir, pergamenske trake za pojačanje hrpta, konzervatorska krema (Leather dressein - Russian formulation) i drugi specijalni materijali.

32 Zaštitna kutija s naslovom knjige „Decretales : Gregorii Noni Pontificis maximi Decretales epistolae...", digitalizirano pri 30 luksa.

${ }_{33}$ Riječ je o analitičkom uvidu muzeologa Maroevića o muzejskom predmetu kao dijelu zbirke u baštinskoj ustanovi. Usp. Maroević, I. Muzejska izložba - muzeološki izazov. // Informatica museologica 34, 3-4(2003), str. 14. Proširimo li međutim pogled s knjige kao medija koji posreduje znanje do jedinstvenog artefakta s pisanim znanjem, naći ćemo se na tlu arheologije knjige. Navedena razmišljanja predmetom su autorovih daljnjih istraživanja koja će biti objavljena u zasebnom radu. 


\subsection{Digitalizacija knjige pomoću sustava za neinvazivnu low light di- gitalizaciju}

Tijekom 2016. godine Knjižnica je započela kvalitetnu suradnju s digitalizacijskim servisom ACOS prigodom obilježavanja 240. obljetnice osnivanja i djelovanja Pravnog fakulteta u Zagrebu. Goran Vržina, vlasnik navedenog digitalizacijskog servisa, tom je prigodom Fakultetu darovao digitalizaciju prethodno restauriranog knjižnog izvornika iz Zbirke starih i rijetkih knjiga iz 16. i 17. stoljeća: Decretales: Gregorii Noni Pontificis maximi Decretales epistolae, vetuitis exemplaribus tum umpressis, tum scriptis non mediceri labore collatis.ab innumeris penemendis, quae hactenus et in contextu et in glossis latebant, recens vibdictae, ... Lugduni, 1528.

Navedenim poslom započeta, a u drugim segmentima nastavljena, ta suradnja odražava visoku razinu profesionalnosti i ostvaruje novu kvalitetu digitalizacije i digitalne obrade osjetljivih i zahtjevnih primjeraka knjižne građe. Pristupom i načinom digitalizacije knjižnog izvornika iz 16. stoljeća pomoću sustava za neinvazivnu low light digitalizaciju, čiji je tvorac upravo G. Vržina, visoko je podignuta razina kriterija provedbe samog postupka digitalizacije i olakšalo se stvaranje kvalitetne dokumentacije u skladu s knjižničarskim, arhivističkim, a osobito muzejskim informacijskim standardima.

\subsubsection{Tehnička obilježja sustava}

Cijeli sustav, zamišljen, dizajniran i fizički realiziran u Hrvatskoj, osmišljen je kao multifunkcionalan uređaj za neinvazivnu beskontaktnu digitalizaciju vrlo niskom razinom svijetla. Sve je u tehničkom smislu započelo 2007. godine. Od prve ideje do gotovog operativnog sustava proteklo je više od deset godina. Taj je sustav lagan i prenosiv te potpuno prilagođen digitalizaciji u prostorima imatelja povijesne građe.

Low light sustavom moguće je digitalizirati kodekse, inkunabule, brojne druge stare i vrijedne izvornike, ali i reljefe te druge plošne originale i predmete: grafike, kovanice, razne vrste transparencija (mikrofilm, film, staklo), diplome, povelje, ikone i dr. Digitalizacija umjetničkih slika i drugih plošnih originala izvodi se u najvišoj mogućoj kvaliteti bez geometrijskih izobličenja i ometajućih refleksija uz autentičnu trodimenzionalnost i teksturu materijala. Sustavom je moguće digitalizirati vrlo širok raspon veličina izvornika, od mikrofilmova pa sve do izvornika znatno većih od dvostrukog A0-formata. Tim su sustavom do sada digitalizirani različiti vrlo vrijedni primjerci tiskane knjižne građe, kao i nekoliko tisuća stranica vrlo rijetkih srednjevjekovnih izvornika od 11. stoljeća nadalje. ${ }^{34}$

34 Među ostalim, valja svakako istaknuti sljedeće: raskošno iluminirani MR 159 Biblia Sollemnis Ecclesiae Cathedralis Zagrebiensis - Gotica 14. stoljeća i MR 156 Biblia Veteris, Testamenti te drugi vrlo stari rukopisi iz Metropolitanske knjižnice u Zagrebu, ukupno više od 5000 stranica. 
Visokovjerne i detaljne digitalne preslike originala moguće je koristiti i kao podloge za restauraciju, kao podloge za izradu faksimila, za reprint, virtualne izložbe i dr. Također valja naglasiti da visokovjerna digitalna preslika originala omogućava njegovo svestrano proučavanje i korištenje u cjelokupnoj raskoši i bogatstvu detalja, oblika, boja i pisane riječi bez potrebe detaljnog opisivanja fizičkih posebnosti izvornika i njegova iznošenja iz repozitorija.

Sustav za low light neinvazivnu digitalizaciju koji radi na opisani način jedinstven je u svijetu. Kvalitetu i veliko zanimanje za primjenu takva načina digitalizacije u baštinskim ustanovama potvrđuju ne samo brojni pozivi, osobito baštinskih ustanova (arhiva, knjižnica i muzeja), za provedbu digitalizacije navedenim sustavom i metodom nego i brojne održane tematske i pokazne radionice, javna predavanja, kao i preporuke te zahvalnice institucija koje su do sada koristile low light neinvazivnu digitalizaciju. ${ }^{35}$

\subsubsection{Digitalizacija izvornika iz 16. stoljeća}

Kako bismo što bolje ilustrirali tijek digitalizacije knjige Decretales : Gregorii Noni Pontificis maximi Decretales epistolae, vetuitis exemplaribus tum umpressis, tum scriptis non mediceri labore collatis.ab innumeris penemendis, quae hactenus et in contextu et in glossis latebant, recens vibdictae, ... Lugduni, 1528. te probleme koji su se pritom pojavili, potrebno je opisati njezine fizičke karakteristike iz perspektive izvršitelja postupka digitalizacije.

Širina knjiga je $31 \mathrm{~cm}$, a visina $43 \mathrm{~cm}$; stranice su približno $1,5 \mathrm{~cm}$ manje po širini i visini. Ukupan broj stranica s koricama je 920. Debljina knjige je približno $5 \mathrm{~cm}$. Korice su presvučene tamnom kožom s otiskom i pozlaćenim detaljima. Zbog svoje veličine i debljine te čvrstih korica, knjiga nije lagana. Stranice su od papira. Listovi su označeni rimskim brojevima. Knjiga je vrlo lijepo i kvalitetno restaurirana, uvez je čvrsto stisnut (slike 3 i 4 ).

Također je digitaliziran značajan broj starih knjiga i raznih izvornika iz drugih ustanova: Državni arhiv u Zagrebu, Hr. Muzej medicine i farmacije - diplome i povelje s pečatima, Institut za etnologiju i folkloristiku i drugi. U sklopu pokazne radionice 5. svibnja 2016. Neinvazivna digitalizacija starih i rijetkih izvornika pri vrlo niskoj razini indirektnog difuznog osvjetljenja u HAZUovoj knjižnici, digitalizirani su: Petar Zoranić, Planine; dvije umjetničke slike - ulje na platnu u bogatim zlatnim okvirima iz Strossmayerove galerije starih majstora u Zagrebu, grafike u tušu na vrlo tankom providnom papiru i dr.

35 O sustavu vidjeti: Vržina, G. Neinvazivna Low Light digitalizacija. // @rhivi 2(2017), 16-17. 

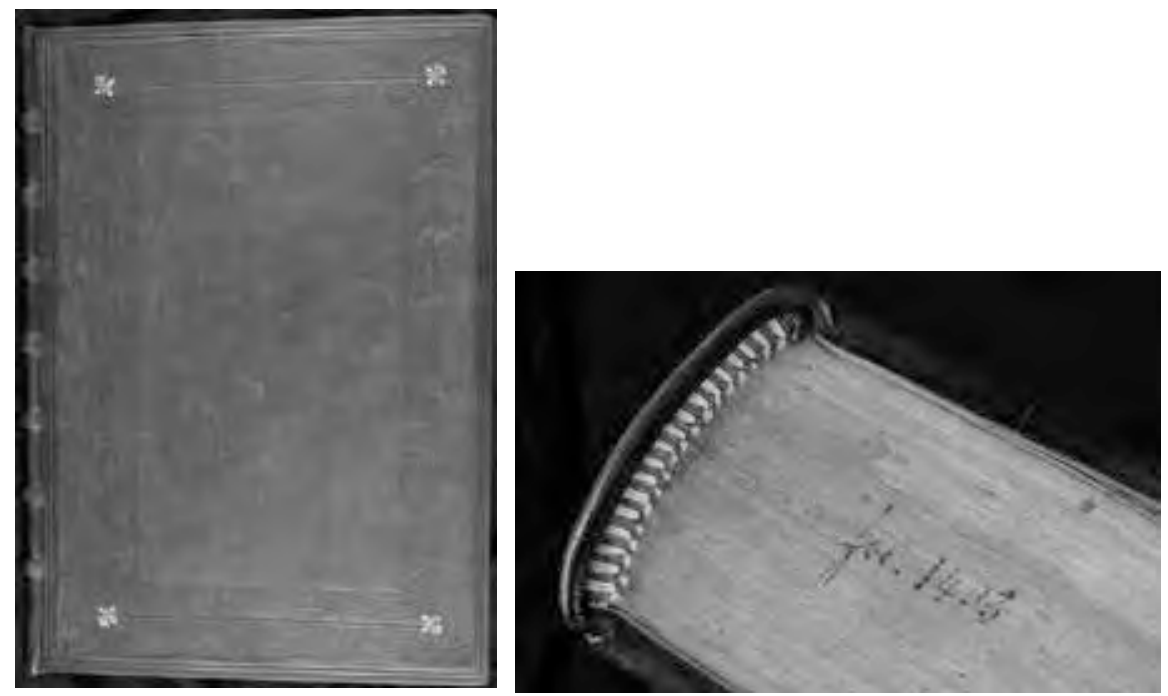

Slika 3. Korice izvornika iz 16 st. Slika 4. Uvez izvornika iz 16. st. ${ }^{36}$

Prilikom postupka restauracije uložen je velik trud da knjiga nakon restauracije izgleda autentično s obzirom na vrijeme u kojemu je nastala. Valja naglasiti da je prilikom pažljivog rastavljanja knjige prije restauracije pronađen 31 fragment papira neidentificiranog rukopisa u koricama koji je sačuvan, zaštićen i digitaliziran. Knjiga se čuva u zaštitnoj kutiji izrađenoj po mjeri. Prilikom pažljiva otvaranja knjige može se vidjeti da čvrsti uvez dopušta otvaranje knjige, ali ne i potpuno izravnavanje stranica. Na spoju stranica recto i verso stvara se duboko uleknuće i do $20 \mathrm{~mm}$ koje se u konačnici oblikuje u neravni procjep između stranica po cijeloj visini knjige. Fizička veza između stranica postavljena je duboko pa nije vidljiva. Kod otvorene knjige zaobljenje stranica prema procjepu počinje se stvarati već $\mathrm{u}$ dijelu gdje postoji tekst te se on u zadnjem dijelu spušta skoro okomito prema samom procjepu. Listovi mjestimično teže stvaranju uzvišenja preko cijele širine stranice (slika 5).

36 Korice i uvez knjige „Decretales : Gregorii Noni Pontificis maximi Decretales epistolae...“, vidljivi su detalji korica i kvalitetan uvez knjižnih blokova, digitalizirano pri 30 luksa. 

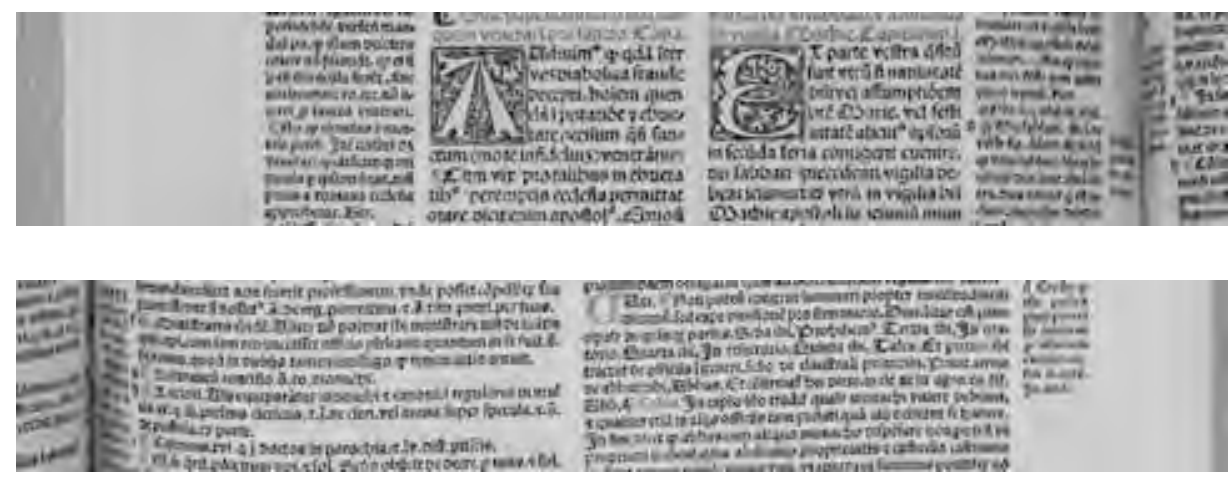

Slika 5. Fragmenti iz korice izvornika ${ }^{37}$

Opisano stvara objektivan problem i velik izazov prilikom digitalizacije primjerka, pri čemu se istovremeno treba izbjeći njezino i najmanje oštećivanje te postići visoka kvaliteta digitalizacije s dobrom čitljivošću. S gledišta očuvanja knjige bilo bi potpuno neprihvatljivo potpuno ju otvoriti i pritisnuti staklom, ali čak ni tada ne bi bilo moguće poravnati stranice do potpunog izravnavanja teksta. Tim načinom gubitak bi bio dvostruk: kvaliteta snimanja bila bi smanjena zbog loma svjetla kroz staklo, a tamo gdje stranice nisu u kontaktu sa staklom (pad stranice prema procjepu - spoju stranica) pojavio bi se osjetan gubitak dubinske oštrine i čitljivosti teksta. Ovdje treba spomenuti da postoje i drugi načini rješavanja tog problema, od kojih je najdrastičniji uklanjanje uveza i hrpta knjige.

S obzirom na to da je knjiga izuzetno vrijedna, kako znanstveno tako i povijesno, potpuno je neprihvatljivo postupak digitalizacije provoditi i s najmanjom mogućnošću njezina oštećenja. Nakon razmatranja prije iznesenih posebnosti knjige, odlučeno je da se njezina digitalizacija mora izvršiti krajnje neinvazivno i bez potpunog otvaranja knjige.

Tijekom digitalizacije opisane knjige posebna je pažnja posvećena vidljivosti teksta koji se spušta prema spoju stranica na sredini knjige, a da se pritom knjiga nije otvarala za više od 120 stupnjeva. Za precizno postavljanje knjige ispod kamere sustava koristio se posebno dizajniran stalak za digitalizaciju knjiga na kojem se može podešavati kut otvaranja knjige, tako da istovremeno bude dobar oslonac knjizi bez mogućnosti oštećenja hrpta i korica knjige. Stalak ima poseban podešavajući dodatak za podršku hrpta debljih, velikih i teških knjiga koje su jako oštećene. Na taj način možemo sigurno i bez straha od daljnjih oštećenja digitalizirati knjige i prije postupka restauracije.

Za digitalizaciju te knjige upotrijebljena je posebna optika kako bi tekst na različitim visinama neravnina stranica bio prikazan oštro i čitljivo te kako bi se

37 Fragmenti iz knjige „Decretales : Gregorii Noni Pontificis maximi Decretales epistolae...“ 
istovremeno postigao autentičan izgled stranica u skladu s izvornikom pri intenzitetu indirektnog difuznog svijetla ispod muzejskog standarda. Digitalizacija je izvršena u visokoj rezoluciji, a digitaliziranoj su knjizi pridodani kolor-etaloni za njezin vjeran reprint. Digitalizirane su i njezine korice te cijela knjiga u prostoru kako bi se sačuvalo što više podataka o njoj. Na kraju su obostrano digitalizirani i pronađeni fragmenti (slika 6).

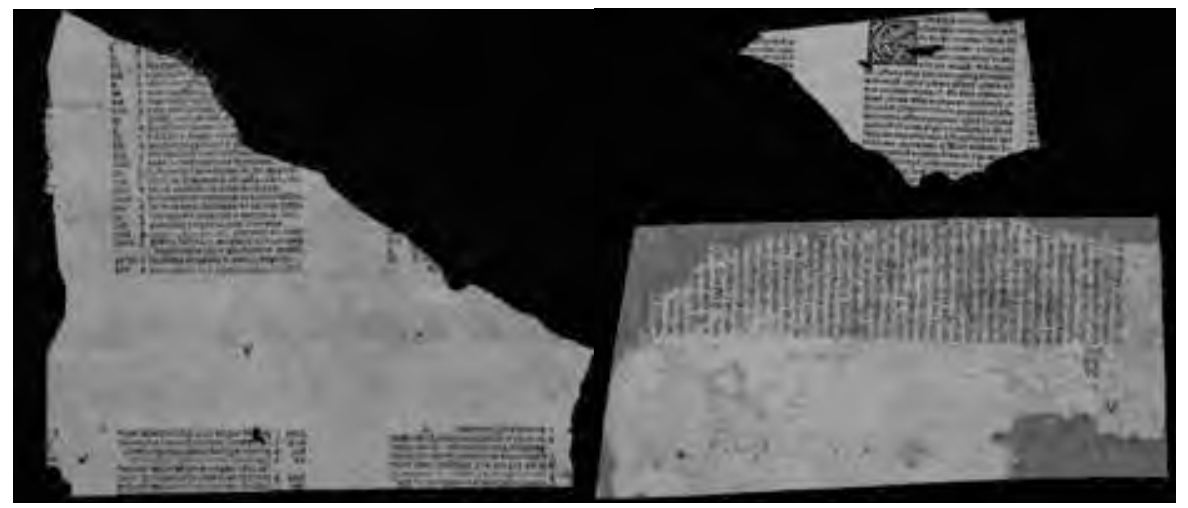

Slika 6. Dodatni fragmenti iz korice izvornika ${ }^{38}$

Postupak digitalizacije ove knjige zahtijevao je mnogo više vremena s obzirom na njezine posebnosti i povijesnu vrijednost. Brzina digitalizacije jako je varirala od stranice do stranice: svakoj je stranici posvećena posebna pažnja. Pridržavanje nekih stranica izvedeno je beskiselinskim štapićima bez zaostalog otiska. Zbog neizbježnih prekida tijekom dugotrajnog postupka digitalizacije knjiga se pokrivala beskiselinskim papirom kako bi rizik od oštećenja prilikom čestih premještanja i ponovnih otvaranja knjige bio što manji.

Knjiga je nakon postupka digitalizacije Knjižnici Pravnog fakulteta vraćena bez oštećenja.

\section{Zaključak}

Iako nevelika, Zbirka rijetkosti Knjižnice Pravnog fakulteta predstavlja prinos korpusu starih i rijetkih knjiga u hrvatskim pravnim knjižnicama kao dijelu nacionalne, ali i europske tiskane baštine. Nad njom se provodi sustavna i trajna zaštita, a od 2016. u pripremi je podzbirka knjiga tiskanih u 18. i prvoj polovici 19. stoljeća koja će se nakon temeljite sadržajne analize i bibliografske obrade

38 Fragmenti iz korica knjige „Decretales : Gregorii Noni Pontificis maximi Decretales epistolae". 
uključiti u program trogodišnje preventivne zaštite prijavom pokretnog kulturnog dobra Gradskom zavodu za zaštitu spomenika kulture i prirode.

$\mathrm{Na}$ konkretnom primjeru u radu je prikazan način provedbe sustavne i trajne zaštite knjižnične građe sa svojstvom kulturnog dobra nakon njezine identifikacije i izdvajanja iz aktivnog knjižničnog fonda, preko procesa inventarizacije, formalne (katalogizacija) i sadržajne (klasifikacija, analitika, unos predmetnih odrednica) obrade te pohrane u prostor s odgovarajućim mikroklimatskim uvjetima.

Digitalizacija se u ovom slučaju provodila nakon provedbe konzervatorsko-restauratorskih postupaka zbog specifičnosti sustava (primjerenosti toj vrsti građe), kao i činjenice da se radilo o vrijednoj donaciji digitalizacije od strane tvrtke Acos iz Zagreba. Kriteriji odabira upravo te jedinice za digitalizaciju usklađeni su s preporukama struke i trendovima u predmetnom području.

Iskustva Knjižnice tijekom provedbe programa zaštite zbirke rijetkosti potvrdila su ne samo potrebu za racionalnim i sustavnim pristupom području zaštite već i ulogu knjižnice u navedenom području. Usprkos paradoksu zaštite koji leži u nemogućnosti trajnog očuvanja „života knjige“ provedbom preventivne i kurativne skrbi, knjižnice i dalje ostaju fizička mjesta za promociju kulture, skrb za očuvanje pismene baštine te izgradnju i razmjenu društvenog i intelektualnog blaga.

\section{LITERATURA}

Brundage, J. Medieval canon law. London; New York: Longman, 1995.

Cloonan, M. V. W(h)ither preservation? // The Library Quarterly 71, 2(2001), 231-242. [citirano 2018-03-08]. Dostupno: http://www.jstor.org/stable/4309507.

Conway, P. Rationale for digitization and preservation. // Handbook for digital projects: a management tool for preservation and acess / ed. by Maxine K. Sitts. Andover, Massachusetts: Northeast Document Conservation Center, 2000. [citirano 2018-0215]. Dostupno na: https://www.nedcc.org/assets/media/documents/dman.pdf.

Croft, J.A. The preservation evolution: a review of preservation literature, 1999-2001. // Library Resources and Technical Services 47, 2(2003), str. 59-71. [citirano 2018-0301]. Dostupno na: https://ia800707.us.archive.org/0/items/lrtsv47no2/lrtsv47no2. pdf.

Đardulo, A. Zaštita i konzervacija knjiga: materijali, tehnike i infrastruktura. Beograd: Clio, 2005. 
Gorman, M. The wrong path and the right path: the role of libraries in access to, and preservation of, cultural heritage. // New Library World 108, 11/12(2007), str. 479-489. [citirano 2018-03-01]. Dostupno: https://doi.org/10.1108/03074800710838236.

Halsted, D. D.; R. P. Jasper; F. M. Little. Disaster planning: a how -to - do -it manual for librarians with planning templates on CD-ROM. New York, London: Neal-Schuman, 2005.

Hasenay, D.; M. Krtalić. Terminološki i metodološki aspekti u proučavanju zaštite stare knjižnične građe. // Libellarium 1, 2(2008), str. 203-220. [citirano 2018-01-28]. Dostupno na: https://hrcak.srce.hr/37156.

Horvat, M. Rimsko pravo. Zagreb: Pravni fakultet Sveučilišta, 2017.

Enciklopedijska natuknica „Breviarium-extravagantium“ [citirano 2017-12-28]. Dostupno na: https://www.britannica.com/topic/Breviarium-extravagantium.

IFLA-in kratki priručnik za pripravnost i planiranje mjera zaštite u slučaju katastrofa. Zagreb: Hrvatsko knjižničarsko društvo, 2012.

IFLA-ina načela za skrb i rukovanje knjižničnom građom. Zagreb: Hrvatsko knjižničarsko društvo, 2003.

Jurić, Š. Stara i rijetka građa. // Seminar Standardiziranje kataložne obrade stare i rijetke građe, Zagreb, 10.-11. prosinca 1992. / ur. Tinka Katić. Zagreb: Nacionalna i sveučilišna biblioteka, 1993. Str. 3-5.

Katić, T. Stara knjiga: bibliografska organizacija informacija. Zagreb: Hrvatsko knjižničarsko društvo, 2007. Str. 39-41.

Kratke smjernice za izradu plana mjera za slučaj opasnosti za narodne knjižnice. Zagreb: Nacionalna i sveučilišna knjižnica, Hrvatski zavod za knjižničarstvo: Matična služba za narodne knjižnice. [citirano 2015-05-20]. Dostupno na: http://www.nsk. $\mathrm{hr} / \mathrm{wp}$-content/uploads/2012/10/Kratke-smjernice-za-izradu-plana-mjera-za-slu\%C4\%8Daj-opasnosti-za-narodne-knji\%C5\%BEnice.pdf.

Krtalić, M.; D. Hasenay; T. Aparac-Jelušić. Upravljanje zaštitom pisane baštine u knjižnicama: teorijske pretpostavke. // Vjesnik bibliotekara Hrvatske 54, 1-2(2011), str. 1-36. [citirano 2018-03-07]. Dostupno i na: https://hrcak.srce.hr/file/119132.

Krtalić, M.; T. Čop; D. Hasenay. Organizacijske pretpostavke zaštite knjižne baštine u samostanskim knjižnicama // Libellarium 3, 2(2010), str. 113-134. [citirano 201801-28]. Dostupno na: https://hrcak.srce.hr/file/115519.

Laszlo, Ž.; A. Dragojević. Priručnik preventivne zaštite umjetnina na papiru. Zagreb: Crescat, 2010.

Laszlo, Ž.; B. Perčinić Kavur; H. Stublić, Što činiti u slučaju nesreće, velike nesreće ili katastrofe? // Informatica Museologica 40, 3-4(2009), str. 134-139. [citirano 201505-20]. Dostupno na: http://hrcak.srce.hr/index.php?show=clanak\&id_clanak_jezik=198480. 
Maroević, I. Muzejska izložba - muzeološki izazov. // Informatica museologica 34, 3-4(2003), str. 13-18. [citirano 2018-02-13]. Dostupno na: https://hrcak.srce. hr/140414.

Medieval manuscripts: bookbinding terms, materials, methods, and models. [citirano 2018-09-13]. Dostupno: https://ravelingscriptorium.files.wordpress.com/2013/07/ bookbinding-booklet.pdf.

Mušnjak, T. Zaštita pisane baštine od kemijskih uzročnika oštećenja. // Savjetovanje Konzerviranje i restauriranje papira 4: grafički materijal, Ludbreg. Zagreb: Hrvatski restauratorski zavod, 2004. Str. 61-68.

Piasevoli, J. Zaštita od štetnog djelovanja svjetla. // Savjetovanje Konzerviranje i restauriranje papira 4: grafički materijal, Ludbreg. Zagreb: Hrvatski restauratorski zavod, 2004. Str. 69-73.

Plathe, A. Uneskov program hitnih mjera za zaštitu vitalnog gradiva u slučaju oružanih sukoba. // Arhivski vjesnik 43(2000), 77-90.

Pravilnik o određivanju kulturnih predmeta koji se smatraju nacionalnim blagom država članica Europske Unije. // Narodne novine 38, 947(2004). [citirano:2018-11-01]. Dostupno na: https://narodne-novine.nn.hr/clanci/sluzbeni/2004_03_38_947.html.

Pravilnik o zaštiti knjižnične građe. // Narodne novine 52, 1001(2005). [citirano: 2018-1101]. Dostupno na: https://narodne-novine.nn.hr/clanci/sluzbeni/2005_04_52_1001. html.

Pravilnik o zaštiti od požara. Zagreb: Pravni fakultet Sveučilišta, 2001.

Procjena rizika od katastrofa za RepublikuHrvatsku/Državna uprava za zaštitu i spašavanje. Zagreb,. <2015>. [citirano 2018-11-02]. Dostupno: https://www.google.hr/url?sa=t\&r$\mathrm{ct}=\mathrm{j} \& \mathrm{q}=\& \mathrm{esrc}=\mathrm{s} \&$ source $=\mathrm{web} \& \mathrm{~cd}=1 \& \mathrm{cad}=\mathrm{rja} \& u a c \mathrm{t}=8 \& \mathrm{ved}=2 \mathrm{ahUKEwi} 6$ PBtLXeAhWrC8AKHYZOAWIQFjAAegQICBAC\&url=http\%3A\%2F\%2Fstari. duzs.hr\%2Fdownload.aspx $\% 3 \mathrm{Ff} \% 3$ Ddokumenti\%2FClanci $\% 2$ FProcjenarizikaodkatastrofauRH..pdf\&usg=AOvVaw2JtuhkrfKUTVIx12sAfVmV.

Smjernice konzervatorsko-restauratorskog rada / priredio Denis Vokić. Dubrovnik; Zagreb: K-R Centar, 2007.

Šalković, J. Kanonsko pravno uređenje u vrijeme Ivana Pavla II. // Ivan Pavao II: poslanje i djelovanje: Zbornik radova sa simpozija održanog u Zagrebu 24. lipnja 2005. Zagreb: Glas Koncila, 2005. Str. 287-306.

Škalabrin, N. Uvod u kanonsko pravo. Zagreb: Katolički bogoslovni fakultet Sveučilišta; Đakovo: Teologija u Đakovu; Osijek: Pravni fakultet Sveučilišta, 1994.

The relevance of preservation in a digital world. // NEDCC preservation leaflets. [citirano: 2018-02-05]. Dostupno na: https://www.nedcc.org/free-resources/preservation-leaflets/6.-reformatting/6.4-the-relevance-of-preservation-in-a-digital-world. 
Tomečak, B. Biblioteka Pravnog fakulteta u Zagrebu: pregled stvaranja knjižnične zbirke i uređenja knjižnice 1886-1964. // Pravni fakultet u Zagrebu / [urednik Željko Pavić]. Zagreb: Pravni fakultet, 1996. Knj. II, sv.1, str. 631-667.

Upute za pristupanje izradi plana mjera za slučaj opasnosti. [citirano:2018-11-01]. Dostupno na: http://www.nsk.hr/wp-content/uploads/2012/01/Upute-PlanMjera-za-slucaj-opasnosti.pdf.

Vržina, G. Neinvazivna Low Light digitalizacija. // @rhivi 2(2017), str. 6-17.

Zakon o knjižnicama: pročišćeni tekst zakona: NN 105/97, 05/98/ 104/00, 69/09. // Zakon.hr. [citirano: 2018-11-01]. Dostupno na: https://www.zakon.hr/z/745/Zakon-o-knji\%C5\%BEnicama. 